\title{
Foreign Bank Identity: Does it Matter for Credit Growth?
}

Caroline Mehigan

TEP Working Paper No. 0716

March 2016

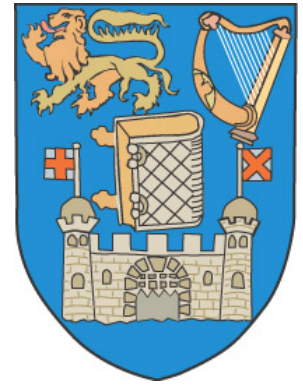

Trinity Economics Papers

\section{Department of Economics}

Trinity College Dublin 


\title{
Foreign Bank Identity: Does it Matter for Credit Growth?
}

\author{
Caroline Mehigan*
}

Trinity College Dublin

\begin{abstract}
This paper provides robust evidence that the home country identity of a foreign-owned bank is an important consideration for credit growth. Among the set of foreign-owned banks we find significant differences in loan growth between banks from advanced than emerging source countries during the Global Financial Crisis. Further, we provide evidence that the regulatory framework prevailing in the home country is correlated with loan growth in the host economy. We show that foreign-owned banks from source countries with higher capital regulatory requirements were associated with significantly less loan growth pre-crisis, but provided a buffer during the crisis.
\end{abstract}

JEL classification: F15, F30, G15, G21

Keywords: Cross-border banking, Foreign-owned banks, Credit growth, Crises.

${ }^{*}$ The author thanks Philip R. Lane for invaluable comments and guidance. The author also greatly appreciates detailed discussion from Martin Brown, Michael King and Rogelio Mercado Jr. Participants at Trinity College Dublin seminars, the Irish Economic Association Annual Conference, The 7th International IFABS Conference and the XXIV International Rome Conference on Money, Banking and Finance have provided very helpful feedback. 


\section{Introduction}

In the context of changing international bank ownership, we ask if the home country identity of foreign-owned banks is relevant for loan growth in the host country. The share of foreign-owned banks is increasing globally. In 1995 foreign owned banks accounted for $20 \%$ of the global sample, by 2009 that figure had increased to 34\%. In 2009 only 12 countries had no foreign bank presence. The increased participation of foreign owned banks in global credit supply is an important motivation to better understand their behaviour.

A second motivation arises from the composition of the set of foreign banks, it is becoming increasingly heterogeneous. The data created by Claessens and Van Horen (2014b) describe the shedding of subsidiaries by Western Europe and North American banks during the crisis, which were picked up by emerging and developing economy owners. To cite a few examples; Russian banks bought Eastern European banks from Austrian owners, while a Colombian bank purchased subsidiaries in Costa Rica, El Salvador and Honduras. Sub Saharan African banks also increased their ownership of overseas banks. In the wake of the financial crisis, Claessens and Van Horen (2014b) show that the crisis has not led to a retrenchment in foreign bank ownership. Rather a structural transformation is under way. The shifting identity of ownership raises questions about credit dynamics. It is likely that the heterogeneity of foreign bank owners is reflected in heterogeneous lending growth by foreign-owned banks. This paper investigates if the identity of the home country is relevant for loan growth in the host economy in the 2006-2009 period. Figure 1 highlights the significant differences in credit growth between banks with emerging and advanced country owners in the crisis period.

The literature has focused on host country differences to explain credit variation by foreignowned banks. Detragiache et al. (2008), Cull and Martínez Pería (2013) and Claessens and Van Horen (2014a) look at income and regional variation in the host economy. Home country characteristics have yet to be explored in this context. If the type of foreign-owned bank is relevant for credit growth, host policy-makers should be aware of financial stability implications associated with different groups of foreign-owned banks. Given that foreign-owned banks are accountable to 
host regulation, a priori, it is not clear that we will find any association between home regulation and credit dynamics in the host economy. However, recent work presented in Ongena et al. (2013) links home country regulation and foreign bank behaviour. They focus on the type of loans (risk profile) offered to firms in the host economy with an Eastern European sample of hosts and Western European source countries. They find that banks facing more stringent regulation at home, participate in riskier loans abroad. In our global sample of home and host economies, we find evidence of regulation pass-through for credit growth. Given the conflicting findings of the two studies, albeit in different settings, we run our model on the Ongena et al. (2013) sample to see if it is sample differences driving the contrasting results. The results are not definitive.

This paper addresses two main questions. Do the credit dynamics of foreign banks differ if they are owned by an emerging or advanced country? Is the regulatory environment in the home country associated with credit growth in the host? To address these questions empirically, we combine three sources of data: bank-level data from Bankscope, bank ownership data from Claessens and Van Horen (2014a) and home country regulation data from Barth et al. (2013). Following the literature, we control for bank characteristics of: size, profitability, capitalization, deposit funding and liquidity. We apply host country fixed effects so we can focus on differences in credit dynamics arising from source country variation. This accounts for the locational choices of banks and conditions in the host economy that would affect credit demand.

We find significant differences in lending behaviour by foreign-owned banks, with different types of home countries. During the pre-crisis period, we report that foreign-owned banks from emerging home countries were associated with significantly lower loan growth than advanced home countries. The opposite is the case for the 2008-2009 crisis years. This finding implies that comparing the loan growth of domestic banks and the set of foreign banks can be misleading. Variation in credit dynamics are concealed when we treat foreign banks as one group.

We extend the analysis to consider whether the regulatory environment in the home country is associated with credit growth in the host. Using the Barth et al. (2008) regulatory data, we explore whether there is evidence of regulation pass-through via foreign-owned banks from source to host 
economies. Given the rich data we analyse three types of regulation: initial capital stringency, restrictions on non-core banking activity and the supervisory power of the regulators. Using principal component analysis we create a factor variable to get an overview of regulation pass through from home country to host.

The results suggest that foreign banks from home countries with higher capital stringency regulatory requirements were associated with significantly less loan growth pre-crisis. During the 2008-2009 period, they were correlated with significantly higher growth than those from home countries with looser capital regulation. This finding is not driven by differences of advanced and emerging home countries. The results are consistent when we control for emerging country ownership.

The paper proceeds as follows. Section 2 details the conceptual framework and reviews the relevant literature. The empirical method is detailed in Section 3, while Section 4 details the data. Section 5 provides the results and discussion and conclusions are offered in Section 6 .

\section{Conceptual Framework}

There is a considerable literature on foreign-owned banks and their effects on the host economies. Host country characteristics are often used to explain the variation in credit behaviour of foreignowned banks. The relevance of the home country identity of the foreign-owned bank for loan growth in the host economy has yet to be analysed. We propose that the identity of the source country is likely to assist in explaining loan growth variation. We investigate whether foreign-owned banks from advanced or emerging home countries differ in their loan growth. We extend the concept to ask whether the regulatory environment of the home country can help explain the differences in loan growth of emerging than advanced home countries.

Primarily, the paper contributes to the growing literature on foreign-owned banks. We focus on the importance of home country identity for credit dynamics. The differences in loan growth have implications for financial stability. Our findings show that it is not enough to know foreign banks are operating in a host economy, it is also important to consider the regulatory environment in the 
home country of the bank. We find that regulation in the home country has interesting implications for credit growth on the host economy.

\subsection{Home Country Identity}

The literature on foreign-owned banks mainly highlights positive effects on the banking system where they operate. They can increase competition, lower overall costs, increase access to funds and increase financial intermediation in an economy. Claessens et al. (2001), Claessens (2006) and Lehner and Schnitzer (2008) provide such evidence. This literature has explored variation in the host country to explain differences in foreign bank behaviour. However, less focus has been placed on the home country identity.

Exceptions are Van Horen (2007) and Claessens and Van Horen (2014b). Van Horen (2007) provides a starting point for our analysis. The paper focuses on foreign banks and their entry into and performance in (efficiency and profitability) emerging economies. The author proposes banks from developing home countries might be more familiar or have a competitive advantage working in a weak investment climate explaining their presence in developing countries. Using bilateral data, the paper looks at home country diversity that may explain locational choices of banks. But unlike her study, in this paper we are concerned with how banks behave once they are in the host economy.

Claessens and Van Horen (2014b) provide further guidance in this area. The paper shows that some bilateral factors are important for the entry and exit of foreign banks but that home and host factors can help explain asset growth between 2007 and 2012. The authors find that home country GDP per capita is significant in explaining asset growth as a home country characteristic. Similarly, they run a cross-country regression on asset growth between 2007 and 2012 for OECD and non-OECD home countries. The results suggest that differences in the home identity should be considered in further detail. We provide evidence of variation in loan growth across advanced and emerging home countries. Further, we uncover that regulation in the home country can help explain these differences. 


\subsection{Loan Growth and Domestic Credit}

Claessens and Van Horen (2014a) find that increased foreign bank participation increases the domestic credit in an economy. The main channel is increased participation. Stiffer competition results in pressure on both lending rates and the volume of credit. However, in low income countries or where there are barriers to entry, foreign banks have been found to "cherry pick" or "cream skim" their clients. This process can lead to lower overall credit in an economy, as found by Detragiache et al. (2008). Essentially, foreign-owned banks can offer more competitive rates and attract the "best" firms in an economy, or "cherry pick" their clients. The domestic banks are then left with a weaker pool of borrowers. To account for these lower quality or higher risk loans, the domestic banks may charge higher rates or issue less loans. This process can lead to an overall reduction in credit in the economy.

Cull and Martínez Pería (2013) find that the behaviour of loan growth by foreign banks differed across regions in the Global Financial Crisis. Their study considered host economies in Eastern Europe and Latin America. They find that foreign banks in Eastern Europe increased lending more than domestic banks pre-crisis, and during the crisis, their lending fell by more than domestic banks. Interestingly, the foreign-owned banks operating in Eastern Europe are mostly subsidiaries of banks with Western European owners. The paper finds different results in Latin America; foreign banks neither increased lending more than domestic banks in the pre-crisis phase nor reduced lending faster in the crisis period. The ownership of foreign banks in Latin America is more varied than that of Eastern Europe. This result leads us to investigate if it is the type of foreign-owned bank that matters. Chen and $\mathrm{Wu}(2014)$ extend the above analysis to include Asia. They introduce the concept of regulation at the host country level to explain variation in loan growth. They find that tighter host country regulation was positively associated with credit growth during the crisis. We are concerned with the regulatory environment in the home country of the foreign-owned bank.

In Chapter 2 of the Global Financial Stability Report Fund (2015), the IMF considered the role of different cross-border banking linkages and domestic credit growth. The report considers home country characteristics and credit growth at the country level. Rather, we are concerned 
with the bank level pass through of ownership characteristics. Furthermore, we are concerned with differences of credit growth within the heterogeneous foreign bank set. The IMF report is focused on the different types of links, such as: cross-border claims, international claims and the local claims of banks.

The literature provides comparisons across domestic, foreign-owned, private or public-owned banks in relation to credit or loan growth. In other cases, the variation in host country characteristics or regional diversity is examined. To the best of our knowledge, no paper has looked at the identity of foreign banks and loan growth. We propose that not only is host identity relevant for credit growth by foreign banks, but so too is the home country identity. Primarily, we analyse if banks from emerging home countries exhibit different loan behaviour than banks from advanced source countries. We extend the analysis and ask whether the regulation environment in the home country is relevant for loan growth in the host. These findings can facilitate policy-makers' understanding of the credit dynamics in their economy.

\subsection{Financial Stability}

Credit dynamics have an important role in financial stability. We relate our work to the literature on foreign banks and financial stability. We provide evidence that home country characteristics are relevant for loan growth in the host. We show that a foreign-owned bank from a tighter regulated home country is associated with more credit growth than a bank with looser home regulation during the Global Financial Crisis.

De Haas and Van Lelyveld (2006) and Goldberg (2009) show that foreign-owned banks can provide stability when a banking system is hit by a systemic shock. However foreign-owned banks can also expose an economy to instability if there is trouble in the home country or globally, as shown by Peek and Rosengren (1997), Peek and Rosengren (2000), Cetorelli and Goldberg (2011) and Schnabl (2012).

The funding structure of the foreign bank is important for crisis behaviour. Foreign-owned banks that are deposit funded are more stable. De Haas and Van Lelyveld (2010) find that funding cuts were less likely in banks financed by deposits. The extent of foreign bank presence in the host 
country is important for behaviour of foreign-owned banks during a crisis. Claessens and Van Horen (2014a) find that foreign banks reduced credit more than domestic banks during the crisis but not when dominant in the host country.

In the context of these studies; our findings show that treating foreign banks as one group can be misleading.

\subsection{Regulation}

We propose regulation in the home country to be associated with loan growth in the host. We adopt the question posed by Ongena et al. (2013): "when the cat's away, the mice will play". Given the opportunity, do subsidiaries participate in more risky behaviour in the host country? Contrastingly, if a home country is tightly regulated, do banks export their conservative behaviour to their foreign subsidiaries? This would be in line with a habit persistence type relation. These two alternatives are plausible. They are likely to differ between crisis and calm periods. Equally, given that subsidiaries are subject to host regulation, there might be no pass through of home regulation on bank behaviour in the host.

Using detailed firm and bank level loan analysis, Ongena et al. (2013) provide evidence that banks from home markets with higher barriers to entry are associated with lower lending standards in the host economy. Similarly, banks from home countries with higher restrictions on non-core bank activity are associated with lower lending standards. Ongena et al. (2013) focus on Western European foreign-owned banks operating in Eastern European countries, while our sample has global coverage. We look at loan growth in the host and regulation in the home country, while their focus is on the lending standards of the foreign subsidiaries. As a complementary step in our analysis we test our model on their sample and compare findings. ${ }^{1}$

The Barth et al. (2013) indices on banking regulation provide data for the analysis. We consider three types of regulation and supervision: restrictions on non-core banking activity, capital stringency and supervisory power. We are particularly interested in capital stringency in the home country, if it is associated with credit growth. Furlong (1992) and Peek and Rosengren (1995) ex-

\footnotetext{
${ }^{1}$ It would be interesting to compare the results of the two studies: i.e. does regulatory pass through differ for lending standards than for credit growth?
} 
amined the link between capital regulation and loan growth within a banking system. We examine the supervisory power in the home country in light of the increased popularity of macro-prudential policy in recent years. In order to get an overall view of these three regulation types, we also use principal component analysis to create an aggregate factor variable.

\section{Empirical Method}

The literature has provided evidence that differences at the host country level can result in variation of loan growth by foreign banks. Using global coverage of bank level data for the period 2006-2009, we investigate whether the home country identity also has a role in understanding credit growth. We employ a panel framework similar to Cull and Martínez Pería (2013) and consider three home identity specifications using interaction terms.

$$
\text { Growth }_{i j k t}=\alpha_{0}+\alpha_{j}+\alpha_{t}+E M_{k}+\text { Crisis }_{t}+\text { Crisis }_{t} * E M_{k}+X_{i j t-1}+\varepsilon_{i j t}
$$

We use an interaction term as opposed to a sample split framework to estimate the model for a number of reasons. Primarily, the bank controls are not static. Allowing these vary with the dependent variable is important. Although the main variable of interest is indeed static, the controls are time varying and as such a panel model is more suited. The combination of bank level data and the need to include host country fixed effects means a panel set up using each year of the data provides more data enabling more accurate estimates. The panel is unbalanced and facilitates the inclusion and estimation of the model on all foreign banks operating during the period. Executing the sample on a balanced panel means only healthy banks are included or those that were foreign owned for the duration. (The main results hold on the balanced panel which constitutes $79 \%$ of the sample.) Using the balanced panel could be misleading as banks that lended aggressively in the boom may have been shut down, gone bust etc. We are not only concerned with successful or healthy foreign banks but all foreign-owned banks for the boom and bust period. This panel framework also allows direct comparison of the type of foreign bank for credit growth before and during the crisis, especially given the unbalanced nature of the panel. Furthermore the main results are consistent if the model is tested on cross sections of a boom and bust setup. 
In the basic model set-up we consider the difference of credit growth by advanced and emerging home countries. Growth $h_{i j k t}$ is the annual growth of loans by bank from home country $_{k}$ in host

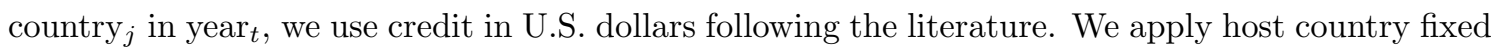
effects in the model $\alpha_{j}$ to control for host specific factors. This removes exchange rate fluctuation at the host level and accounts for a host being in crisis effects as found in De Haas and Van Lelyveld (2006) on credit growth. The host fixed effects also control for factors that attracted the subsidiary to locate in that country initially, highlighted by Van Horen (2007). We also apply time fixed effects to the model, $\alpha_{t}$. The inclusion of time fixed effects controls for common to all shocks or global effects. Given the time period under consideration, these control positive credit growth in the run up to the crisis and the likely reduction of credit growth during the crisis. The specifications are estimated using pooled OLS.

The emerging variable is a dummy at the home country level that takes a value of one if the home country is an emerging economy and zero if it is advanced. ${ }^{2}$. The coefficient on this dummy variable can be interpreted as the difference in credit growth by emerging than advanced home country banks for the pre-crisis period. The crisis variable has a value of one for the years 2008 and 2009. ${ }^{3}$ The interaction term coefficient assists in understanding the role of identity during the crisis. To see the different credit behaviour of an emerging bank than an advanced during the crisis we sum the coefficients of the interaction term and the emerging dummy variable.

$X_{i j t-1}$ is a vector of bank specific characteristics common to the literature on credit growth. We use the lagged values of these variables to reduce potential endogeneity issues. Common to both Chen and Wu (2014) and Cull and Martínez Pería (2013) we control for: bank size; the profitability of the bank; the capitalization of the bank; funding stability; and the liquidity of the bank. Table 1 presents bank level summary statistics.

Chen and $\mathrm{Wu}(2014)$ pointed to the relevance of regulation at the host country level for credit growth. Although the foreign owned banks are not subject to home country regulation it is plausible

\footnotetext{
${ }^{2}$ The advanced countries are Australia, Austria, Belgium, Canada, Denmark, Finland, France, Germany, Greece, Iceland, Ireland, Italy, Japan, Luxembourg, Malta, Netherlands, New Zealand, Norway, Portugal, Spain, Sweden, Switzerland, United Kingdom, United States, all other economies are coded as emerging.

${ }^{3}$ Excluding time fixed effects and running separate 2008 and 2009 crisis dummy variables yields similar results.
} 
that there is persistence in bank behaviour across borders as outlined in Ongena et al. (2013). In order to get a clearer idea of potential regulatory pass through, we run a specification using three indices created by Barth et al. (2013). A higher index value indicates more restrictive regulation.

$$
\text { Growth }_{i j k t}=\alpha_{0}+\alpha_{j}+\alpha_{t}+R E G_{k}+\text { Crisis }_{t}+\text { Crisis }_{t} * R E G_{k}+X_{i j t-1}+\varepsilon_{i j t}
$$

We run these regressions separately due to correlation among the regulatory measures. First, we consider the index for restrictions on non-core banking activities as an explanatory variable (values can range from (3-14)). Second, we use the initial capital stringency regulation index. Finally, we use the index for official supervisory power, indicating whether the supervisors have power to take specific actions to prevent and correct problems, the values range (1-14). In order to get an aggregate interpretation, we construct a factor variable from the three indices using principal component analysis. The principal component analysis reduces the regulation data into their basic components, removing unnecessary parts. ${ }^{4}$

Our final specification helps to uncover which type of variation; (regulation or advanced and emerging differences at the home country level) is relevant for loan growth. We estimate the model with the regulation variables and control for emerging home country ownership.

$$
\begin{array}{r}
\text { LoanGrowth }_{i j k t}=\alpha_{0}+\alpha_{j}+R E G_{k}+E M_{k}+\text { Crisis }_{t}+\text { Crisis }_{t} * R E G_{k}+ \\
\text { Crisis }_{t} * E M_{k}+X_{i j t-1}+\varepsilon_{i j t}
\end{array}
$$

What is of most interest in this specification is whether the regulatory environment in the home country can drive out the significance of the emerging/advanced home country split.

As a final step in the analysis, we run our model on the samples used by Ongena et al. (2013). We run the specification three times, once with their European source countries and global host sample, then with a global source sample and the Ongena et al. (2013) host sample, and finally with the same country sample as in their analysis. To be clear, their paper addresses whether the type of loans issued by foreign banks is associated with the level of bank regulation in the source country, they also consider the risk profile of the borrowers, whether banks that lend to riskier

\footnotetext{
${ }^{4}$ The Kaiser criterion suggests to retain factors with eigenvalues greater than or equal to one. In this paper, following this specification we retain Factor 1, with an eigenvalue of 1.66 . Factor 1 corresponds to $55 \%$ of the total variance.
} 
borrowers abroad face tighter restrictions at home. We are concerned with the loan growth of foreign banks. In other words, our study focuses on the quantity or growth of credit, while they focus on the quality of the loans. Both studies uses bank level data for credit growth, they also have firm level data for the loan recipient which adds an extra layer to the study. In our global sample we find that banks facing tighter capital regulation at home export this more conservative behaviour, in their European sample they find that banks take on more risk once they are able to. If using the same samples we find consistent results as theirs, it would appear that European banks behave differently to the global sample of foreign banks. If instead we don't find consistent evidence in the loan growth of European banks, we can conclude that foreign owned banks from Europe, pursue riskier lending overseas but in quality, there isn't a quantity effect which is what our model captures.

\section{Data}

\subsection{Foreign Ownership}

The data on foreign bank ownership are provided by Claessens and Van Horen (2014a). The coverage of banking systems is broad, detailing 137 countries for the period 1995-2009. The data accounts for 90 per cent or more of a countries banking assets. The authors define a bank as foreign owned if 50 percent or more of its shares are held by foreigners. This cut-off is typical of the literature on foreign banking. The ownership is applied on a direct basis. ${ }^{5}$

We present summary statistics on a regional basis for source and host country loan growth in Table 3. At a regional level, we see that the main source countries of foreign banks are OECD economies for both the pre-crisis and crisis periods. Also evident is the increased participation of regions between the two periods, for example Sub-Saharan African banks had 79 links with overseas banks for 2005-2007 but this had increased to 100 for the 2007-2009 period. Banks from the Middle East and North Africa also increased their presence abroad from 23 to 31 links in 2009. Table 3 also reports the number of foreign bank links for the crisis and pre-crisis periods and the mean loan growth on a host country basis. This table gives a clear indication of the country coverage of the

\footnotetext{
${ }^{5}$ For a detailed discussion of foreign ownership refer to Claessens and Van Horen (2014a)
} 
data. It also highlights the negative loan growth experienced by many host countries during the crisis. In our sample we analyse banks from 78 different source countries. This table indicates the variation in loan growth by source country and across the periods of interest for this paper.

\subsection{Bank Level Data}

We restrict our analysis to the period 2006-2009, corresponding to the significant improvement (since 2005) in coverage for asset and loan data provided by Bankscope. Our analysis requires a one year lag, thus we use the 2005 data. The purpose of the paper is to uncover if the home country identity of a foreign bank is relevant in explaining credit growth in the host economy. We look at all foreign-owned banks as defined by Claessens and Van Horen (2014a). However, if we restrict our sample to only those banks that are present in each year 2005-2009, the main findings hold. Evidence is provided by Claessens and Van Horen (2014a) of significant entry and exit of banks during the period, executing the specification on a "healthy" bank sample may be misleading.

Bankscope provides data on domestic banks and foreign owned subsidiaries. Banks do not typically report branch balance sheets, so our sample consists of foreign-owned subsidiaries. The bank-level variables are all sourced from Bankscope, produced by Bureau van Dijk. The variable we use for loan growth is gross loans. It is the growth in local lending provided by foreign-owned banks from home country $k$ in host country $j$. The bank specific controls are bank size, log of total assets; profitability, return on assets; capitalization, equity to loan ratio; liquidity condition, liquid assets to total assets ratio; funding stability, retail deposits to total liability ratio. Table 1 provides summary statistics. Broadly; emerging banks are smaller in terms of asset size, rely more on deposits, are higher capitalized and are more liquid than advanced banks. Tables 4 and 5 provides a regional breakdown of source economies of bank level summary statistics. For the pre-crisis period foreign banks with OECD or MENA owners were the most capitalized on average. Banks with South Asian or Sub Saharan African owners had the highest levels of deposit funding, while Europe and Central Asian owned banks relied least on deposit funding. There is less variety by regional ownership for liquidity, although Latin American owned foreign banks had lowest liquidity ratios. Banks with owners from the Europe and Central Asia were the most profitable or had the 
highest return on assets, while Latin American banks were the least profitable. Finally banks from OECD source countries were the largest in terms of asset size and those with owners from Eastern Asia and the Pacific were the smallest on average.

\subsection{Regulation data}

The regulation and supervision data are sourced from the Barth et al. (2013) database. We use the indices resulting from the 2005 survey round, corresponding to Barth et al. (2008). The data are collected from detailed surveys co-ordinated by the World Bank (almost three hundred questions) completed by central bank officials in each country. The questions span the supervision and regulation of banks in 142 countries. The authors then compile the survey responses into indices that can be used in empirical research. It is important to note that we use the static values of 2005 regulation indices for our analyses. We have chosen the 2005 value as these values are exogenous to loan growth in the later years. If instead later values of regulation were used there would be causality issue. For example, did the source countries that changed their capital adequacy rations do so because banks had issued too much credit or vice versa. We use indices measuring regulation on bank activities, capital regulation and official supervisory power. The index of restrictions on non-core banking activities is based on the following questions: (1) The extent to which banks may engage in underwriting, brokering and dealing in securities and all aspects of the mutual fund industry; (2) the extent to which banks may engage in insurance underwriting and selling; and (3) the extent to which banks may engage in real estate investment, development and management.

The official supervisory power index is constructed from 14 questions. The index is designed to see whether the supervisory authorities have the authority to take specific actions to prevent and correct problems. The questions range from the power to replace bank directors to supervisors meeting with external auditors.

The capital stringency index only covers 68 countries, or half the countries in our sample. As a result we use the initial capital stringency index which provides full coverage. The initial capital stringency index is created from the following questions: (1) are the sources of funds classified as capital verified by the regulatory or supervisory authorities?; (2) can the initial disbursement and 
subsequent injections of capital be executed with assets other than cash or government securities?; (3) can the initial disbursement of capital be executed with borrowed funds? In Table 6 we report summary statistics for the regulation variables from the source country perspective. We see that OECD countries had the loosest capital stringency regulation on average, while Southern Asia and the MENA region had the most stringent rules. Latin America has the tightest restrictions on non-core banking activity. Banks originating from Other High Income countries gave the highest level of supervisory power to their Central Banks. In order to get an overall view of home country regulation, we use principal component analysis to create a factor variable. We combine the three indices outlined above to do so.

In summary, we use the foreign ownership data from Claessens and Van Horen (2014a), match them to bank level data from Bankscope, and merge with home country characteristics using Barth et al. (2013). This provides a globally representative database we can use to investigate whether the home country of a foreign bank matters for credit dynamics in the host country.

\section{Empirical Analysis}

We begin by considering the variation in the loan growth of foreign-owned banks from emerging countries versus advanced source countries. Figure 1 illustrates the median loan growth of foreign banks split by advanced or emerging home countries. Interestingly, credit growth was increasing for 2006-2007 for the median foreign-owned bank of either advanced or emerging origin. The variation is striking for the crisis period. The median bank in our sample from an advanced country had substantially lower loan growth in 2008 and close to zero growth in 2009.

Figure 2 depicts the median loan growth of foreign banks split by advanced or emerging home countries in advanced host countries, while Figure 3 does the same for emerging host economies. In both charts, there appear to be significant differences in loan growth by foreign banks from emerging than advanced home countries for the crisis. Emerging-owned banks increased credit more in advanced hosts throughout the period. Credit growth in 2008 is particularly divergent across advanced and emerging country owned foreign banks. 
The annual median values of the banking variables are provided in Table 1 . The figures show that the median emerging foreign-owned bank was more profitable, had a greater dependence on deposit funding and was better capitalized than the median advanced bank for the period. It is clear that the median advanced bank was significantly larger than an emerging source bank in this sample. Table 2 provides summary statistics on the regulation data created by Barth et al. (2008). For each regulatory measure, the average source emerging economy had tighter regulation than the average advanced country.

\subsection{Loan Growth and Asset Growth}

In Table 7, we report the results from estimating equation (1). In the first column, we report the specification applied to annual loan growth, column (2) refers to asset growth. We include asset growth here as a robustness check. The two series are correlated, but in this paper we are concerned with credit growth so primarily use the loan series.

In both specifications, we see that a foreign-owned bank from an emerging home country is associated with significantly lower loan growth pre-crisis. In the years preceding the crisis, an emerging foreign-owned bank had 6.6 percentage points less credit growth than an advanced home country. The crisis years 2008-2009 have a significant negative effect on loan growth. During the crisis however foreign-owned banks from emerging countries had significantly higher relative credit growth than banks from advanced home economies. Summing the coefficient of the "Emerging Owner" and the "Emerging Owner" interacted with "Crisis", emerging owned banks had almost 5 percentage points more loan growth than foreign banks with advanced owners during the crisis.

The control variables throughout the specifications are consistent with the literature. Larger banks are associated with less annual loan growth, so too are more profitable banks. Banks with higher capital and liquidity are correlated with higher credit growth. The funding stability variable, which considers the extent of deposits as a source of funding is not consistently significant across

the specifications. This control is important in the literature when comparing loan growth between domestic and foreign owned banks De Haas and Van Lelyveld (2006). It would appear it is not so relevant for explaining differences among foreign-owned subsidiaries. 


\subsection{Loan Growth and Home Country Regulation}

In Table 8 we present the results of the estimation of equation (2). Each column corresponds to the different measure of regulation used in the specification. In order to get an overall view, we used principal component analysis of the three measures of regulation to obtain an aggregate regulatory index. The results are presented in column (1). The regulation coefficient is significant and negative, implying countries with tighter regulation are associated with less credit growth in the pre-crisis period. The coefficient on the interaction term suggests banks with tighter regulation in the home country had higher credit growth during the crisis.

In column (2), we consider the restriction of non-core activity in the home country on loan growth by the bank in the host economy. The measure is insignificant included alone, implying that pre-crisis, there was no association with non-core regulation at home and loan growth abroad. During the crisis period it gains significance. This result suggests that during the crisis, foreign owned banks from home countries with higher restrictions on non-core activity were associated with higher credit growth in the host.

The results using the index of initial capital stringency are reported in column (3). Banks of home countries with more stringent capital requirements are correlated with lower credit growth before the crisis. This result is significant at the 1 percent level. During the crisis the opposite is found, banks from home countries with stricter initial capital requirements provided a 4 percent buffer during the crisis.

Finally in column (4), we report the results of the specification including the supervisory power of the home country regulator. We find home country supervisory powers are associated with credit growth in the host. More supervisory powers have a negative relation with credit growth prior to the crisis but, they have a positive effect during the crisis period.

Overall the regulation on bank capital in the source country has the strongest association with credit growth in the host economy. Foreign-owned banks with tighter capital regulation are associated with less loan growth pre-crisis, so too for banks from countries with high supervisory power. However during 2008-2009, foreign banks that faced tighter regulation at home had significantly 
greater credit growth in the host economy. These findings provide evidence of regulation pass through from home to host economies via foreign banks. This is relevant for policy-makers: the type or identity of foreign banks is important to better understand the credit dynamics in domestic markets.

\subsection{Loan Growth and Home Country Regulation, Controlling for Emerg- ing Country Variation}

Next, we consider Table 9. This specification includes the regulation variables while controlling for an emerging home country dummy. We are interested whether the regulation variables can drive out the significance of the emerging country dummy.

The first column presents the results for the overall regulatory environment in the source economy. Outlined in the empirical method, we compute this variable using principal component analysis. Our main interest is whether controlling for emerging ownership, regulation differences in the source country are still significant. The regulation variable drives out the significance of the emerging dummy. This implies that for the pre-crisis period, banks from home countries with more stringent regulation were associated with less credit growth. For the 2008-2009 period, foreign banks increased credit relatively more when their home economy was tightly regulated controlling for emerging country ownership. The insignificance of the emerging owner variable emphasises that the relevant identity is the regulatory regime in the home country.

Column (2) reports the results for regulation of non-core activity in the home country. Neither emerging country ownership nor restrictions on non-core bank activity are associated with loan growth pre-crisis. During the crisis, however, banks from home countries with more regulation of non-core activities are correlated with relatively higher growth. The same is true for banks with owners from emerging countries. These results suggest both regulation of non-core activities and emerging bank ownership at the home country level can both explain the differences in loan growth during the crisis.

In column (3), we consider if the stringency of capital requirements at home are associated with loan growth in the host countries, controlling for emerging country ownership. Again the results 
show that regulation in the home country is not just picking up differences between advanced and emerging countries. More stringent regulation in the home country is associated with less loan growth in the host pre-crisis, controlling for an emerging home country. In the 2008-2009 period, we see that foreign owned banks with stricter initial capital regulation are associated with higher credit growth.

In the final column, we investigate if the supervisory power of the home country is associated with loan growth in the host country when we control for emerging home countries. In this instance, we see that the supervisory environment is not significantly associated with credit growth in the host before or during the crisis. The fact that a bank has an emerging country owner explains the variation rather than the power of regulators in the home country.

In summary, we have shown that the identity of the home country of a foreign-owned bank is important. We find evidence that there is pass-through of behaviour by foreign banks from home to host markets. This pass through of higher regulation is not fully explained by advanced or emerging country differences in the case of capital regulation.

\subsection{Comparison with Ongena et al. (2013) Findings}

Ongena et al. (2013) found higher regulation at home led to riskier lending behaviour overseas. Their sample was based on Eastern European banks with Western European owners. In a global sample, we show that tighter capital regulation at home appears to follow through to the host country. Subsidiaries from tightly regulated home markets were associated with relatively less loan growth in the pre-crisis period, and relatively more growth during the crisis.

The contrast in the results of the two papers warrants further examination. In order to do this we create a sub sample of the Ongena et al. (2013) host and source countries. We run our model on their sample to better understand the result. First we look and see is it the banks from Western Europe that are driving the result, then if the result is coming from the sample of host countries. Finally we run the model on the same sample as Ongena et al. (2013).

To be consistent with their analysis we use two forms of regulation, restrictions on non-core banking activities and capital stringency. Primarily we analyse the restrictions of non-core banking 
activity. In column (1) of Table 10 the results for the sample of Western European source countries are presented. We find that banks increased lending significantly more overseas if they faced tighter restrictions on bank behaviour in their home market during the boom period, to all hosts. This finding is consistent with the Ongena et al. (2013), and in contrast to our findings. This suggests foreign banks from this Western European sample behave differently to the global sample. When we run the model on foreign banks in the Eastern European host sample, we find smaller, insignificant coefficients however their signs are consistent with the Ongena et al. (2013). Finally when we run the same sample as used by Ongena et al. (2013) at both host and source level we find insignificant results.

We interpret these results that this Western European sample of foreign owned banks appear to play when the cats away during the boom period. Western European banks from countries that faced more restrictions on non core banking activity increased credit growth faster than those banks with less restriction on their non-core banking activity. However, that the finding doesn't hold in the precise Ongena et al. (2013) country sample implies that loan growth and the types of loans offered or risk profiles have different relationships with home country regulation. Our paper is concerned with loan growth and it finds that banks from countries with tighter regulation increase the volume of loans less than those facing looser regulation on non-core activity at home. The Ongena et al. (2013) on a restricted European sample finds that banks take risk when they can if they are tightly regulated at home. The comparison of the results suggests that they do this really along the quality of loans by issuing riskier types; rather then the quantity.

11 presents the regression results for the initial capital stringency measure of regulation. Interestingly it is again the regression using the sample of Western European owned banks that provides significant results. here we report that banks from countries in Western Europe with higher initial capital stringency rules increased credit significantly during the crisis. This finding is consistent with our main findings, that foreign owned banks originating in countries with higher capital stringency rules increased credit growth more, (or provided a buffer) during the crisis relative to banks from looser regulated economies. There are no significant findings in the remaining samples in 11. 
Overall comparing the two studies, it is clear that regulation is in the home country is important for the behaviour of subsidiaries in the host economies. The two studies differ in country samples and also the unit measured, further our study focuses on the quantity of the credit while Ongena et al. (2013) examine the quality or riskiness of the loan. Both papers find that there is a relationship between the regulation in the home country and how the subsidiary behaves in the host. These findings warrant further investigation in the literature and increased understanding of the mechanisms at play.

\subsection{Robustness}

Importantly, our findings hold when conditioning on a number of robustness checks. As outlined in Table 7, our results are robust to using the asset growth of foreign owned banks and are not only relevant for loan growth. We use narrow and broad( OECD member countries) measures of advanced country samples and the results are not sensitive to different definitions. In the analysis we use a narrow advanced country sample. Similarly the results hold if we exclude the United States or United Kingdom from the sample.

We winsorize the dependent variables, and all continuous variables at the 1st and 99th percentile to account for outliers. Further the findings hold if we exclude the top $1 \%$ and $5 \%$ of loan growth observations; so that our findings are not driven by outliers. We also run the specifications on the sample of banks that are in every year of the sample, obtaining similar results.

For robustness, we look into subsets of the data. Analysing the set of foreign-owned banks with only advanced country owners provides consistent results. We find that foreign-owned banks with tighter capital regulation are associated with less credit growth pre-crisis, and more growth in 2008-2009. This adds further weight to the regulation pass through hypothesis.

The role of foreign-owned banks and crisis transmission in widely debated. In the context of this paper, we run additional specifications and control for banking crises in the home country. ${ }^{6}$ The findings of regulation pass through holds in these settings.

\footnotetext{
${ }^{6}$ We follow Valencia and Laeven (2012) to define banking crises.
} 


\section{Conclusion}

This paper investigates whether home country characteristics of foreign banks can assist in explaining loan growth in the host country. We provide new evidence that the advanced or emerging nature of the home country was important for loan growth of foreign-owned banks in the 2006-2009 period. Furthermore, we show that the regulatory framework of the home (advanced or emerging) country is related to loan growth in the host economy. Capital regulation is specifically important for this relation. Foreign-owned banks from countries with tighter capital regulatory requirements are associated with significantly less loan growth pre-crisis, and provided a buffer during the crisis. These findings are important for banking sector stability. In the changing landscape of foreign ownership of banks, these results highlight the importance of considering the type of foreign bank for credit dynamics of an economy.

In the context of previous literature, the paper compares and complements Ongena et al. (2013). We find that banks facing tighter capital regulation at home do not increase the volume of loans through loan growth, while Ongena et al. (2013) report that tighter regulation is associated with the issuing of riskier profile of loans. Thus it appears to be a quantity and quality relationship between regulation at home and foreign bank behaviour. 


\section{References}

Barth, J. R., Caprio, G., and Levine, R. 2008. Bank regulations are changing: For better or worse. Comparative Economic Studies, 50(4):537-563.

Barth, J. R., Caprio Jr, G., and Levine, R. 2013. Bank regulation and supervision in 180 countries from 1999 to 2011. Journal of Financial Economic Policy, 5(2):111-219.

Cetorelli, N. and Goldberg, L. S. 2011. Global banks and international shock transmission: Evidence from the crisis. IMF Economic Review, 59(1):41-76.

Chen, G. and Wu, Y. 2014. Bank ownership and credit growth in emerging markets during and after the 2008-2009 financial crisis- a cross regional comparision. IMF Working Paper wp/14/171, International Monetary Fund.

Claessens, S. 2006. Access to financial services: A review of the issues and public policy objectives. The World Bank Research Observer, 21(2):207-240.

Claessens, S. and Van Horen, N. 2014a. Foreign banks: Trends and impact. Journal of Money, Credit and Banking, 46(s1):295-326.

Claessens, S. and Van Horen, N. 2014b. The impact of the global financial crisis on banking globalization. Discussion paper, CEPR.

Claessens, S., Demirgüç-Kunt, A., and Huizinga, H. 2001. How does foreign entry affect domestic banking markets? Journal of Banking \& Finance, 25(5):891-911.

Cull, R. and Martínez Pería, M. S. 2013. Bank ownership and lending patterns during the 20082009 financial crisis: Evidence from latin america and eastern europe. Journal of Banking $\mathcal{E}$ Finance, 37(12):4861-4878.

De Haas, R. and Van Lelyveld, I. 2006. Foreign banks and credit stability in central and eastern europe. a panel data analysis. Journal of banking \& Finance, 30(7):1927-1952. 
De Haas, R. and Van Lelyveld, I. 2010. Internal capital markets and lending by multinational bank subsidiaries. Journal of Financial Intermediation, 19(1):1-25.

Detragiache, E., Tressel, T., and Gupta, P. 2008. Foreign banks in poor countries: theory and evidence. The Journal of Finance, 63(5):2123-2160.

Fund, I. M. 2015. Navigating Monetary Policy Challenges and Managing Risks. Global financial stability report, International Monetary Fund.

Goldberg, L. S. 2009. Understanding banking sector globalization. IMF Staff Papers, 56(1):171.

Lehner, M. and Schnitzer, M. 2008. Entry of foreign banks and their impact on host countries. Journal of Comparative Economics, 36(3):430-452.

Ongena, S., Popov, A., and Udell, G. F. 2013. when the cat's away the mice will play: Does regulation at home affect bank risk-taking abroad? Journal of Financial Economics, 108(3): $727-750$.

Peek, J. and Rosengren, E. 1995. The capital crunch: neither a borrower nor a lender be. Journal of Money, Credit and Banking, pages 625-638.

Peek, J. and Rosengren, E. S. 1997. The international transmission of financial shocks: The case of japan. The American Economic Review, pages 495-505.

Peek, J. and Rosengren, E. S. 2000. Collateral damage: Effects of the japanese bank crisis on real activity in the united states. American Economic Review, pages 30-45.

Schnabl, P. 2012. The international transmission of bank liquidity shocks: Evidence from an emerging market. The Journal of Finance, 67(3):897-932.

Valencia, F. and Laeven, L. 2012. Systemic Banking Crises Database: An Update. IMF Working Papers 12/163, International Monetary Fund.

Van Horen, N. 2007. Foreign banking in developing countries; origin matters. Emerging Markets Review, 8(2):81-105. 
Figure 1: All Foreign-Owned Banks

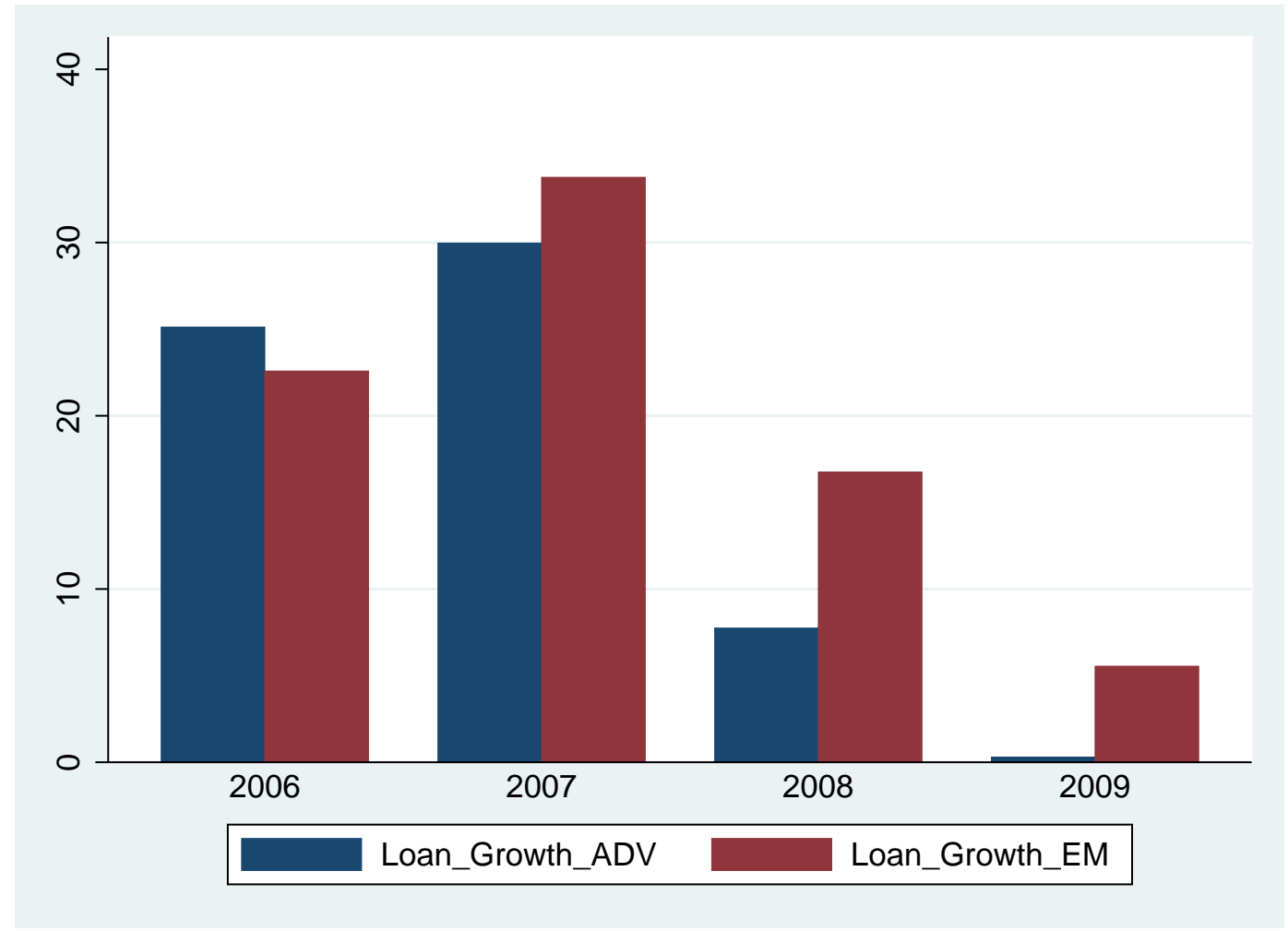

Note: The graph depicts differences in loan growth by foriegn banks between emerging and advanced home countries. The data are annual growth in loans sourced from Bankscope. The home country ownership data are taken from Claessens and Van Horen (2014a) 
Figure 2: Foreign-Owned Banks in Advanced Host Countries

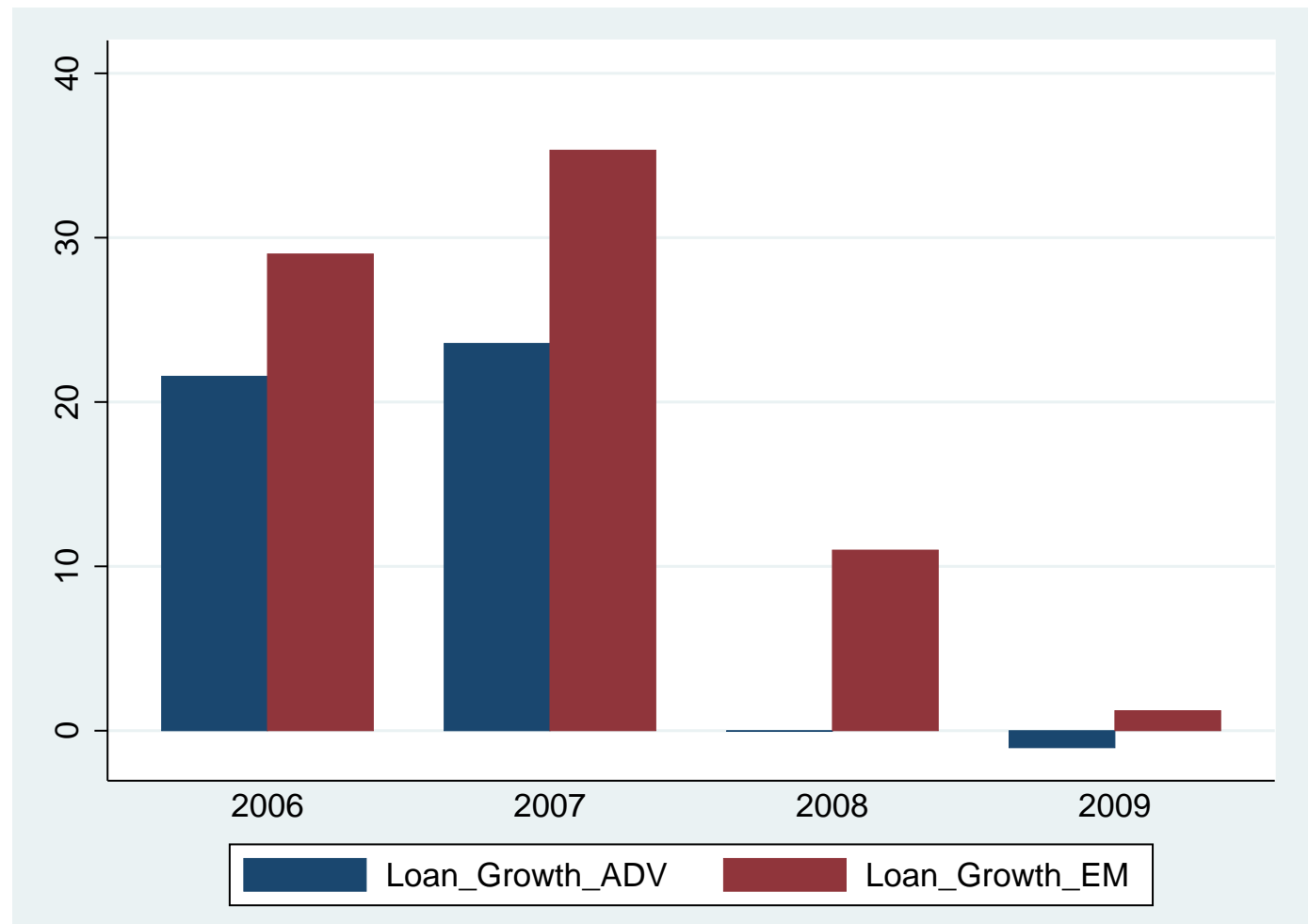

Note: The graph depicts differences in loan growth by advanced country owned foreign banks between emerging and advanced host countries. The data are annual growth in loans sourced from Bankscope. The home country ownership data are taken from Claessens and Van Horen (2014a) 
Figure 3: Foreign-Owned Banks in Emerging Host Countries

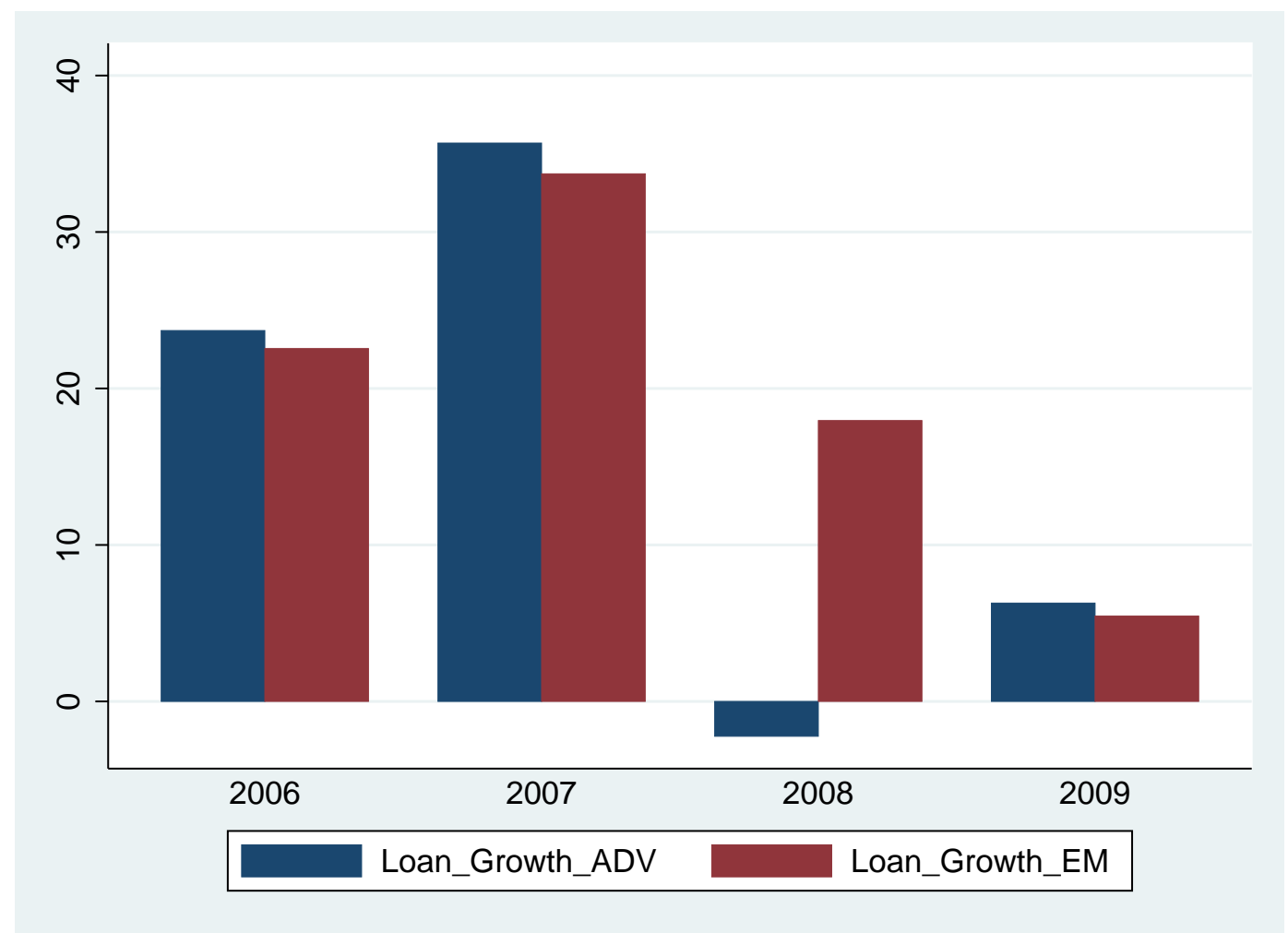

Note: The graph depicts differences in loan growth by emerging owned foreign banks between emerging and advanced host countries. The data are annual growth in loans sourced from Bankscope. The home country ownership data are taken from Claessens and Van Horen (2014a) 
Table 1: Bank Level Summary Statistics

\begin{tabular}{|c|c|c|c|}
\hline \multicolumn{2}{|l|}{ MEDIAN VALUES } & \multirow{2}{*}{$\frac{\text { EMERGING }}{22.58}$} & \multirow{2}{*}{$\frac{\text { ADVANCED }}{25.12}$} \\
\hline \multirow{4}{*}{$\begin{array}{l}\text { LOAN } \\
\text { GROWTH }\end{array}$} & 2006 & & \\
\hline & 2007 & 33.77 & 29.97 \\
\hline & 2008 & 16.76 & 7.75 \\
\hline & 2009 & 5.54 & 0.30 \\
\hline \multirow{4}{*}{$\begin{array}{l}\text { TOTAL ASSETS } \\
\text { (\$ MILLIONS) }\end{array}$} & 2006 & 244.66 & 1239.94 \\
\hline & 2007 & 337.39 & 1788.34 \\
\hline & 2008 & 375.86 & 1906.58 \\
\hline & 2009 & 430.14 & 1814.28 \\
\hline \multirow{4}{*}{$\begin{array}{l}\text { PROFITABILITY } \\
\text { (RETURN ON ASSETS) }\end{array}$} & 2006 & 1.43 & 1.10 \\
\hline & 2007 & 1.41 & 1.06 \\
\hline & 2008 & 1.19 & 0.82 \\
\hline & 2009 & 0.97 & 0.57 \\
\hline \multirow{4}{*}{$\begin{array}{l}\text { CAPITALIZATION } \\
\text { (RATIO EQUITY:LOANS) }\end{array}$} & 2006 & 11.49 & 9.45 \\
\hline & 2007 & 11.74 & 9.41 \\
\hline & 2008 & 12.04 & 9.58 \\
\hline & 2009 & 12.37 & 10.65 \\
\hline \multirow{4}{*}{$\begin{array}{l}\text { LIQUIDITY } \\
\text { (LIQUID ASSETS/ } \\
\text { TOTAL ASSETS) }\end{array}$} & 2006 & 41.23 & 39.34 \\
\hline & 2007 & 39.55 & 39.24 \\
\hline & 2008 & 34.39 & 33.51 \\
\hline & 2009 & 34.68 & 32.45 \\
\hline \multirow{4}{*}{$\begin{array}{l}\text { FUNDING STABILITY } \\
\text { (RETAIL DEPOSITS/ } \\
\text { TOTAL LIABILITIES) }\end{array}$} & 2006 & 0.69 & 0.58 \\
\hline & 2007 & 0.69 & 0.55 \\
\hline & 2008 & 0.67 & 0.51 \\
\hline & 2009 & 0.70 & 0.57 \\
\hline
\end{tabular}

Note: Bank level data are sourced from Bankscope, home country ownership data are taken from Claessens and Van Horen (2014a).

Table 2: Regulation Summary Statistics

\begin{tabular}{|c|c|c|c|c|c|c|c|c|c|}
\hline & \multicolumn{3}{|c|}{ Non-Core Bank Activity } & \multicolumn{3}{|c|}{ Supervisory Power } & \multicolumn{3}{|c|}{ Initial Capital Stringency } \\
\hline & Min & Max & Mean & Min & $\operatorname{Max}$ & Mean & Min & $\operatorname{Max}$ & Mean \\
\hline Emerging & 3 & 12 & 8.5 & 5 & 16 & 11.4 & 0 & 3 & 2.3 \\
\hline Advanced & 3 & 9 & 6.6 & 6 & 14.5 & 10.1 & 0 & 3 & 1.7 \\
\hline
\end{tabular}

Note: Data are calculated using Barth et al. (2008). 
Table 3: Regional Summary Statistics for Loan Growth

\begin{tabular}{|c|c|c|c|c|c|c|c|c|c|}
\hline Region & & $\mathrm{n}$ & Mean & S.D. & Min & 0.25 & Mdn & 0.75 & Max \\
\hline EAP & & 21 & 22 & 27 & -66 & 11 & 22 & 46 & 56 \\
\hline ECA & & 29 & 64 & 46 & -7 & 26 & 58 & 107 & 152 \\
\hline LAC & PRE-CRISIS & 69 & 19 & 45 & -218 & 10 & 18 & 31 & 219 \\
\hline MENA & Source & 23 & 33 & 56 & -134 & 15 & 34 & 62 & 156 \\
\hline OECD & Loan Growth & 611 & 35 & 60 & -207 & 12 & 28 & 51 & 575 \\
\hline OHI & & 22 & 28 & 26 & -43 & 22 & 30 & 42 & 69 \\
\hline SA & & 16 & 36 & 29 & -6 & 19 & 27 & 53 & 92 \\
\hline SSA & & 79 & 32 & 32 & -51 & 12 & 28 & 49 & 199 \\
\hline EAP & & 25 & 11 & 29 & -47 & -7 & 11 & 24 & 99 \\
\hline ECA & CRISIS & 37 & 22 & 55 & -48 & -11 & 2 & 37 & 243 \\
\hline LAC & Source & 70 & 5 & 58 & -282 & -7 & 4 & 24 & 128 \\
\hline MENA & Loan Growth & 31 & 20 & 23 & -25 & 8 & 16 & 30 & 85 \\
\hline OECD & & 721 & 5 & 58 & -387 & -12 & 4 & 22 & 483 \\
\hline $\mathrm{OHI}$ & & 30 & 9 & 18 & -22 & -1 & 3 & 15 & 60 \\
\hline SA & & 19 & 18 & 18 & -18 & 5 & 19 & 28 & 54 \\
\hline SSA & & 100 & 23 & 33 & -72 & 5 & 26 & 37 & 160 \\
\hline EAP & & 36 & 29 & 32 & -43 & 12 & 25 & 45 & 140 \\
\hline ECA & & 222 & 46 & 48 & -199 & 24 & 42 & 65 & 364 \\
\hline LAC & Pre-Crisis & 161 & 31 & 69 & -218 & 10 & 22 & 36 & 575 \\
\hline MENA & Host & 24 & 41 & 29 & -26 & 22 & 39 & 56 & 110 \\
\hline OECD & Loan Growth & 225 & 23 & 59 & -207 & 3 & 21 & 39 & 326 \\
\hline OHI & & 27 & 49 & 43 & -7 & 20 & 36 & 61 & 189 \\
\hline SA & & 11 & 94 & 142 & 3 & 24 & 34 & 57 & 388 \\
\hline SSA & & 164 & 29 & 33 & -134 & 13 & 24 & 45 & 199 \\
\hline EAP & & 59 & 5 & 44 & -232 & -12 & 7 & 24 & 110 \\
\hline ECA & Crisis & 279 & 11 & 50 & -387 & -6 & 9 & 29 & 243 \\
\hline LAC & Source & 191 & 13 & 67 & -282 & -7 & 5 & 31 & 483 \\
\hline MENA & Loan Growth & 28 & 16 & 19 & -21 & 3 & 15 & 26 & 62 \\
\hline OECD & & 246 & -9 & 63 & -319 & -26 & -1 & 13 & 239 \\
\hline OHI & & 29 & 12 & 39 & -47 & -2 & 6 & 16 & 181 \\
\hline SA & & 14 & -1 & 17 & -31 & -15 & -3 & 13 & 30 \\
\hline SSA & & 187 & 19 & 33 & -62 & 2 & 16 & 31 & 235 \\
\hline
\end{tabular}

Note:Bank level data are sourced from Bankscope, home country ownership data are taken from Claessens and Van Horen (2014a). The regions are defined as EAC; Europe and Central Asia, EAP; East Asia Pacific, LAC; Latin America and Caribbean, MENA; Middle East and Northern Africa, OECD, OHI; Other High income countries, SA; South Asia, SSA; Sub Saharan Africa. 
Table 4: Regional Summary Statistics Bank Controls for Pre-Crisis Source Countries

\begin{tabular}{|c|c|c|c|c|c|c|c|c|c|}
\hline REGION & VARIABLE & $\mathrm{n}$ & Mean & S.D. & Min & 0.25 & Mdn & 0.75 & Max \\
\hline EAC & & 29 & 0.05 & 0.04 & 0.01 & 0.02 & 0.04 & 0.06 & 0.18 \\
\hline EAP & & 21 & 0.14 & 0.17 & 0.01 & 0.04 & 0.08 & 0.13 & 0.69 \\
\hline LAC & & 69 & 0.21 & 0.41 & 0.01 & 0.02 & 0.03 & 0.08 & 1.58 \\
\hline MENA & & 23 & 0.42 & 1.06 & 0.02 & 0.04 & 0.08 & 0.19 & 4.77 \\
\hline OECD & Capitalization & 611 & 0.58 & 3.24 & 0 & 0.03 & 0.07 & 0.18 & 46.34 \\
\hline $\mathrm{OHI}$ & & 22 & 0.07 & 0.05 & 0.01 & 0.04 & 0.06 & 0.09 & 0.24 \\
\hline $\mathrm{SA}$ & & 16 & 0.13 & 0.1 & 0.01 & 0.05 & 0.09 & 0.21 & 0.32 \\
\hline SSA & & 79 & 0.09 & 0.08 & 0.01 & 0.03 & 0.06 & 0.13 & 0.4 \\
\hline EAC & & 29 & 0.38 & 0.27 & 0.01 & 0.16 & 0.32 & 0.61 & 0.89 \\
\hline EAP & & 21 & 0.55 & 0.28 & 0.07 & 0.39 & 0.61 & 0.8 & 0.91 \\
\hline $\mathrm{LAC}$ & & 69 & 0.63 & 0.3 & 0.02 & 0.51 & 0.73 & 0.81 & 1.58 \\
\hline MENA & Deposit Funding & 23 & 0.47 & 0.21 & 0.03 & 0.34 & 0.47 & 0.6 & 0.86 \\
\hline OECD & & 611 & 0.5 & 0.28 & 0 & 0.26 & 0.56 & 0.75 & 0.96 \\
\hline $\mathrm{OHI}$ & & 22 & 0.61 & 0.18 & 0.17 & 0.53 & 0.68 & 0.73 & 0.85 \\
\hline SA & & 16 & 0.75 & 0.12 & 0.46 & 0.71 & 0.76 & 0.86 & 0.91 \\
\hline SSA & & 79 & 0.72 & 0.14 & 0.2 & 0.66 & 0.75 & 0.81 & 0.94 \\
\hline EAC & & 29 & 0.24 & 0.12 & 0.05 & 0.18 & 0.24 & 0.29 & 0.58 \\
\hline EAP & & 21 & 0.39 & 0.21 & 0.09 & 0.22 & 0.4 & 0.49 & 0.76 \\
\hline LAC & & 69 & 0.27 & 0.23 & 0.05 & 0.13 & 0.19 & 0.3 & 0.92 \\
\hline MENA & Liquidity & 23 & 0.38 & 0.21 & 0.15 & 0.23 & 0.32 & 0.47 & 0.97 \\
\hline OECD & & 611 & 0.36 & 0.25 & 0 & 0.16 & 0.31 & 0.5 & 0.97 \\
\hline OHI & & 22 & 0.36 & 0.13 & 0.04 & 0.27 & 0.35 & 0.47 & 0.57 \\
\hline SA & & 16 & 0.37 & 0.23 & 0.05 & 0.2 & 0.31 & 0.58 & 0.75 \\
\hline SSA & & 79 & 0.36 & 0.18 & 0.07 & 0.22 & 0.32 & 0.49 & 0.72 \\
\hline EAC & & 29 & 1.12 & 1.77 & -2.7 & 0.04 & 1.08 & 2.29 & 4.2 \\
\hline EAP & & 21 & 2 & 1.82 & -1.67 & 1.24 & 1.58 & 3.29 & 5.41 \\
\hline LAC & & 69 & 0.48 & 6.92 & -45.15 & 0.71 & 1.77 & 2.26 & 6.41 \\
\hline MENA & Profitability & 23 & 1.84 & 3.67 & -9.18 & 0.48 & 2.25 & 3.73 & 11.68 \\
\hline OECD & & 611 & 1.18 & 3.03 & -32.41 & 0.35 & 1.01 & 2.19 & 21.84 \\
\hline OHI & & 22 & 0.85 & 2.29 & -6.29 & 0.43 & 1.25 & 2.13 & 3.7 \\
\hline SA & & 16 & 1.8 & 0.78 & 0.56 & 1.14 & 1.84 & 2.53 & 3.1 \\
\hline SSA & & 79 & 1.48 & 2.65 & -14.5 & 0.96 & 1.84 & 3.23 & 5.04 \\
\hline EAC & & 29 & 5.63 & 1.33 & 3.61 & 4.43 & 5.72 & 6.92 & 7.95 \\
\hline EAP & & 21 & 5.25 & 0.62 & 3.93 & 4.84 & 5.39 & 5.71 & 6.05 \\
\hline LAC & & 69 & 5.39 & 1.42 & 2.69 & 4.39 & 5.6 & 6.52 & 8.35 \\
\hline MENA & & 23 & 5.98 & 1.64 & 2.73 & 5.09 & 5.51 & 6.87 & 9.01 \\
\hline OECD & Size & 611 & 7.18 & 1.89 & 2.85 & 5.83 & 6.96 & 8.42 & 13.41 \\
\hline $\mathrm{OHI}$ & & 22 & 6.21 & 1.33 & 3.27 & 5.58 & 6.06 & 7.53 & 8.66 \\
\hline SA & & 16 & 5.53 & 1.43 & 3.85 & 4.83 & 5.25 & 5.54 & 9.09 \\
\hline SSA & & 79 & 5.27 & 1.22 & 2.91 & 4.32 & 5.33 & 6.09 & 8.18 \\
\hline
\end{tabular}

Note:The regions are defined as EAC; Europe and Central Asia, EAP; East Asia Pacific, LAC; Latin America and Caribbean, MENA; Middle East and Northern Africa, OECD, OHI; Other High income countries, SA; South Asia, SSA; Sub Saharan Africa. 
Table 5: Regional Summary Statistics: Bank Controls for Crisis Period Source Countries

\begin{tabular}{|c|c|c|c|c|c|c|c|c|c|}
\hline REGION & VARIABLE & $\mathrm{n}$ & Mean & S.D. & Min & 0.25 & Mdn & 0.75 & Max \\
\hline EAC & & 37 & 0.04 & 0.03 & 0.01 & 0.02 & 0.03 & 0.06 & 0.13 \\
\hline EAP & & 25 & 0.1 & 0.1 & 0.02 & 0.03 & 0.06 & 0.1 & 0.47 \\
\hline LAC & & 70 & 0.24 & 0.45 & 0.01 & 0.02 & 0.04 & 0.21 & 2.03 \\
\hline MENA & & 31 & 0.08 & 0.08 & 0.02 & 0.03 & 0.05 & 0.09 & 0.36 \\
\hline OECD & Capitalization & 721 & 0.35 & 1.23 & 0 & 0.02 & 0.05 & 0.17 & 22.75 \\
\hline $\mathrm{OHI}$ & & 30 & 0.05 & 0.05 & 0 & 0.03 & 0.04 & 0.07 & 0.24 \\
\hline SA & & 19 & 0.07 & 0.07 & 0.01 & 0.03 & 0.03 & 0.13 & 0.24 \\
\hline SSA & & 100 & 0.08 & 0.09 & 0.01 & 0.03 & 0.05 & 0.09 & 0.8 \\
\hline EAC & & 37 & 0.45 & 0.23 & 0.03 & 0.24 & 0.42 & 0.63 & 0.86 \\
\hline EAP & & 25 & 0.52 & 0.27 & 0.03 & 0.3 & 0.63 & 0.68 & 0.9 \\
\hline LAC & & 70 & 0.58 & 0.29 & 0 & 0.35 & 0.71 & 0.8 & 0.93 \\
\hline MENA & Deposit Funding & 31 & 0.52 & 0.21 & 0.04 & 0.35 & 0.55 & 0.66 & 0.89 \\
\hline OECD & & 718 & 0.5 & 0.27 & 0 & 0.27 & 0.54 & 0.73 & 0.94 \\
\hline $\mathrm{OHI}$ & & 30 & 0.6 & 0.19 & 0.16 & 0.44 & 0.62 & 0.78 & 0.9 \\
\hline $\mathrm{SA}$ & & 19 & 0.8 & 0.12 & 0.61 & 0.74 & 0.78 & 0.87 & 1.16 \\
\hline SSA & & 100 & 0.72 & 0.14 & 0.04 & 0.65 & 0.74 & 0.81 & 0.93 \\
\hline EAC & & 37 & 0.24 & 0.12 & 0.06 & 0.13 & 0.23 & 0.36 & 0.48 \\
\hline EAP & & 25 & 0.35 & 0.17 & 0.1 & 0.22 & 0.34 & 0.41 & 0.71 \\
\hline LAC & & 70 & 0.32 & 0.22 & 0.03 & 0.16 & 0.25 & 0.42 & 0.93 \\
\hline MENA & Liquidity & 31 & 0.31 & 0.15 & 0.13 & 0.23 & 0.27 & 0.36 & 0.75 \\
\hline OECD & & 721 & 0.33 & 0.24 & 0 & 0.14 & 0.26 & 0.47 & 1.33 \\
\hline $\mathrm{OHI}$ & & 30 & 0.28 & 0.17 & 0.04 & 0.17 & 0.24 & 0.37 & 0.86 \\
\hline $\mathrm{SA}$ & & 19 & 0.28 & 0.2 & 0.09 & 0.14 & 0.21 & 0.5 & 0.7 \\
\hline SSA & & 100 & 0.31 & 0.15 & 0.06 & 0.2 & 0.26 & 0.39 & 0.8 \\
\hline EAC & & 37 & -0.48 & 3.03 & -7.77 & -2.27 & 0.29 & 1.32 & 3.89 \\
\hline EAP & & 25 & 1.72 & 1.4 & -1.18 & 0.75 & 1.43 & 2.55 & 4.19 \\
\hline LAC & & 70 & 1.5 & 2.53 & -6.52 & 0.5 & 1.54 & 2.46 & 6.59 \\
\hline MENA & Profitability & 31 & 2.41 & 3.14 & -4 & 0.7 & 1.83 & 3.97 & 10.34 \\
\hline OECD & & 720 & 0.46 & 4.58 & -82.26 & 0.01 & 0.66 & 1.71 & 14.57 \\
\hline OHI & & 30 & -0.07 & 2.7 & -10.76 & 0.07 & 0.5 & 1.05 & 2.89 \\
\hline SA & & 19 & 3.2 & 4.36 & 0.08 & 1.52 & 2.29 & 2.81 & 20.21 \\
\hline SSA & & 100 & 1.28 & 2.96 & -12.95 & 0.64 & 1.61 & 2.47 & 8.16 \\
\hline EAC & & 37 & 5.98 & 1.6 & 2.41 & 4.74 & 5.7 & 7.3 & 8.8 \\
\hline EAP & & 25 & 5.86 & 0.93 & 4.15 & 5.19 & 5.82 & 6.08 & 7.5 \\
\hline LAC & & 70 & 5.44 & 1.74 & 0.77 & 4.02 & 5.7 & 6.99 & 8.49 \\
\hline MENA & & 31 & 6.08 & 1.47 & 3.2 & 5.3 & 6.07 & 7.21 & 9 \\
\hline OECD & Size & 721 & 7.32 & 1.89 & 1.88 & 5.95 & 7.18 & 8.57 & 13.53 \\
\hline OHI & & 30 & 6.75 & 1.28 & 4.18 & 6.13 & 6.78 & 7.78 & 8.6 \\
\hline $\mathrm{SA}$ & & 19 & 5.53 & 1.44 & 3.96 & 4.7 & 5.11 & 5.94 & 8.91 \\
\hline SSA & & 100 & 5.54 & 1.08 & 3.67 & 4.64 & 5.43 & 6.4 & 8.07 \\
\hline
\end{tabular}

Note: The regions are defined as EAC; Europe and Central Asia, EAP; East Asia Pacific, LAC; Latin America and Caribbean, MENA; Middle East and Northern Africa, OECD, OHI; Other High income countries, SA; South Asia, SSA; Sub Saharan Africa. 
Table 6: Regional Summary Statistics for Regulation Variables

\begin{tabular}{|c|c|c|c|c|c|c|c|c|c|}
\hline Region & Variable & N. & Mean & S.D. & Min & 0.25 & Mdn & 0.75 & Max \\
\hline EAP & & 21 & 2.1 & 0.3 & 2 & 2 & 2 & 2 & 3 \\
\hline ECA & & 29 & 2.17 & 0.38 & 2 & 2 & 2 & 2 & 3 \\
\hline LAC & & 69 & 2.38 & 0.55 & 1 & 2 & 2 & 3 & 3 \\
\hline MENA & & 23 & 2.7 & 0.47 & 2 & 2 & 3 & 3 & 3 \\
\hline OECD & Initial Capitial Stringency & 611 & 1.91 & 0.68 & 0 & 1 & 2 & 2 & 3 \\
\hline OHI & & 22 & 2.36 & 0.95 & 1 & 1 & 3 & 3 & 3 \\
\hline SA & & 16 & 3 & 0 & 3 & 3 & 3 & 3 & 3 \\
\hline SSA & & 79 & 2.46 & 0.5 & 2 & 2 & 2 & 3 & 3 \\
\hline EAP & & 21 & 7.62 & 0.92 & 7 & 7 & 7 & 8 & 10 \\
\hline ECA & & 29 & 6.93 & 1.41 & 6 & 6 & 6 & 9 & 9 \\
\hline LAC & & 69 & 8.81 & 1.18 & 7 & 8 & 9 & 10 & 11 \\
\hline MENA & Non-Core Banking Activity & 23 & 8.43 & 0.51 & 8 & 8 & 8 & 9 & 9 \\
\hline OECD & & 611 & 6.27 & 1.74 & 3 & 5 & 6 & 8 & 9 \\
\hline OHI & & 22 & 7.68 & 0.48 & 7 & 7 & 8 & 8 & 8 \\
\hline SA & & 16 & 8.13 & 0.5 & 8 & 8 & 8 & 8 & 10 \\
\hline SSA & & 79 & 8.41 & 0.98 & 8 & 8 & 8 & 8 & 11 \\
\hline EAP & & 21 & 12.4 & 2.26 & 10 & 11 & 11 & 15.5 & 15.5 \\
\hline ECA & & 29 & 8.95 & 2.01 & 8 & 8 & 8 & 9 & 14.5 \\
\hline LAC & & 69 & 12.63 & 1.42 & 10 & 12 & 12 & 14 & 14.5 \\
\hline MENA & Supervisory Power of Regulators & 23 & 12.02 & 1.12 & 10 & 12 & 12.5 & 12.5 & 13 \\
\hline OECD & & 611 & 10.13 & 2.81 & 6 & 8 & 8.5 & 14 & 14.5 \\
\hline OHI & & 22 & 13.11 & 1.39 & 10 & 13.5 & 13.5 & 14 & 14 \\
\hline SA & & 16 & 10.25 & 1 & 10 & 10 & 10 & 10 & 14 \\
\hline SSA & & 79 & 11.04 & 1.85 & 5 & 10 & 12 & 12 & 14 \\
\hline
\end{tabular}

Note: Data are calculated using Barth et al. (2008). 
Table 7: Loan and Asset Growth

\begin{tabular}{lcc}
\hline & $(1)$ & $(2)$ \\
& Loan Growth & Asset Growth \\
\hline & & \\
Emerging Owner & $-6.66^{* *}$ & $-10.43^{* * *}$ \\
& $(3.01)$ & $(2.57)$ \\
Crisis & $-27.93^{* * *}$ & $-27.03^{* * *}$ \\
& $(2.68)$ & $(2.19)$ \\
Size & $-3.97^{* * *}$ & $-5.60^{* * *}$ \\
& $(0.84)$ & $(0.69)$ \\
Capitalization & $8.82^{* * *}$ & $-2.80^{* *}$ \\
& $(2.86)$ & $(1.15)$ \\
Profitability & $-2.17^{* * *}$ & -0.52 \\
& $(0.58)$ & $(0.50)$ \\
Deposit Funding & -0.12 & 3.84 \\
& $(4.74)$ & $(3.70)$ \\
Liquidity & 0.99 & $-11.06^{* *}$ \\
& $(6.70)$ & $(4.37)$ \\
Emerging * Crisis & $12.56^{* * *}$ & $16.92^{* * *}$ \\
& $(3.51)$ & $(2.84)$ \\
Host Country F.E. & & \\
Year F.E. & Yes & Yes \\
Observations & 2,288 & 2,294 \\
R-squared & 0.22 & 0.25 \\
\hline
\end{tabular}

Note: The models are estimated using ordinary least squares. The crisis variable is a dummy for the years 2008-2009. The dependant variable and all continuous variables are winsorized at the 1st and 99th percentile. Bank level data are sourced from Bankscope, home country ownership data are taken from Claessens and Van Horen (2014a). Bank regulation data are sourced from Barth et al. (2013). Robust standard errors are in parentheses. $* * *$ Significant at $1 \%, * *$ Significant at $5 \%,{ }^{*}$ Significant at $10 \%$. 
Table 8: Loan Growth and Home Country Regulation

\begin{tabular}{lcccc}
\hline & & & & \\
& Overall Reg & Non-Core Banking & Initial Capital \\
& $(\mathrm{PCA})$ & Activity & Stringency & $\begin{array}{c}\text { Suprvisory } \\
\text { Power }\end{array}$ \\
\hline \multirow{2}{*}{ Regulation } & & & & \\
& $-4.15^{* *}$ & -0.95 & $-5.59^{* * *}$ & $-1.14^{*}$ \\
Crisis & $(1.80)$ & $(0.83)$ & $(1.94)$ & $(0.62)$ \\
& $-24.76^{* * *}$ & $-44.06^{* * *}$ & $-43.43^{* * *}$ & $-39.99^{* * *}$ \\
Size & $(2.48)$ & $(7.17)$ & $(5.40)$ & $(8.59)$ \\
& $-4.88^{* * *}$ & $-3.62^{* * *}$ & $-4.11^{* * *}$ & $-4.98^{* * *}$ \\
Capitalization & $(0.94)$ & $(0.83)$ & $(0.84)$ & $(0.91)$ \\
& $10.28^{* * *}$ & $9.22^{* * *}$ & $9.37^{* * *}$ & $10.66^{* * *}$ \\
Profitability & $(2.79)$ & $(2.76)$ & $(2.72)$ & $(2.73)$ \\
& $-2.07^{* * *}$ & $-2.28^{* * *}$ & $-2.14^{* * *}$ & $-2.06^{* * *}$ \\
Deposit Funding & $(0.63)$ & $(0.59)$ & $(0.58)$ & $(0.62)$ \\
& 4.93 & 0.55 & -0.26 & 4.63 \\
Liquidity & $(5.34)$ & $(4.79)$ & $(4.80)$ & $(5.34)$ \\
& -7.40 & -3.86 & -1.38 & -5.41 \\
Regulation $*$ Crisis & $(6.97)$ & $(6.56)$ & $(6.66)$ & $(6.99)$ \\
& $7.13^{* * *}$ & $2.80^{* * *}$ & $9.61^{* * *}$ & $1.56^{* *}$ \\
& $(2.03)$ & $(0.97)$ & $(2.35)$ & $(0.77)$ \\
Host Country F.E. & & & & \\
Year F.E. & Yes & Yes & Yes & Yes \\
Observations & 1,903 & Yes & Yes & Yes \\
R-squared & 0.24 & 2,187 & 2,211 & 1,943 \\
\hline & & 0.22 & 0.22 & 0.24 \\
\hline
\end{tabular}

Note: The dependant variable is annual loan growth. The models are estimated using ordinary least squares. The crisis variable is a dummy for the years 2008-2009. The dependant variable and all continuous variables are winsorized at the 1st and 99th percentile. Bank level data are sourced from Bankscope, home country ownership data are taken from Claessens and Van Horen (2014a). Bank regulation data are sourced from Barth et al. (2013). Robust standard errors are in parentheses. ${ }^{* * *}$ Significant at $1 \%,{ }^{* *}$ Significant at $5 \%,{ }^{*}$ Significant at $10 \%$. 
Table 9: Loan Growth, Home Country Regulation Controlling for Emerging Ownership

\begin{tabular}{lcccc}
\hline & & & & \\
& Overall Reg & Non-Core Banking & Initial Capital & Supervisory \\
Pctivity & Stringency & Power \\
\hline \multirow{2}{*}{ Regulation } & & & & \\
& $-3.37^{*}$ & -0.32 & $-4.50^{* *}$ & -0.83 \\
Emerging Owner & $(2.03)$ & $(0.91)$ & $(1.96)$ & $(0.64)$ \\
& -3.26 & -5.65 & -4.87 & $-6.87^{* *}$ \\
Crisis & $(3.84)$ & $(3.48)$ & $(3.24)$ & $(3.48)$ \\
& $-26.63^{* * *}$ & $-40.21^{* * *}$ & $-42.44^{* * *}$ & $-37.48^{* * *}$ \\
Size & $(2.92)$ & $(7.47)$ & $(5.37)$ & $(8.68)$ \\
& $-4.88^{* * *}$ & $-3.68^{* * *}$ & $-4.08^{* * *}$ & $-4.96^{* * *}$ \\
Capitalization & $(0.96)$ & $(0.85)$ & $(0.87)$ & $(0.94)$ \\
& $10.26^{* * *}$ & $9.16^{* * *}$ & $9.28^{* * *}$ & $10.56^{* * *}$ \\
Profitability & $(2.79)$ & $(2.77)$ & $(2.71)$ & $(2.72)$ \\
& $-2.07^{* * *}$ & $-2.29^{* * *}$ & $-2.15^{* * *}$ & $-2.07^{* * *}$ \\
Deposit Funding & $(0.63)$ & $(0.59)$ & $(0.58)$ & $(0.62)$ \\
& 4.88 & 0.49 & -0.30 & 4.62 \\
Liquidity & $(5.33)$ & $(4.78)$ & $(4.80)$ & $(5.32)$ \\
& -7.23 & -3.61 & -1.13 & -5.19 \\
Regulation * Crisis & $(6.98)$ & $(6.56)$ & $(6.65)$ & $(6.97)$ \\
& $5.71^{* *}$ & $1.89^{*}$ & $7.61^{* * *}$ & 0.94 \\
Emerging * Crisis & $(2.41)$ & $(1.10)$ & $(2.44)$ & $(0.81)$ \\
& 6.21 & $7.99^{*}$ & $9.85^{* *}$ & $12.79^{* * *}$ \\
Host Country F.E. & $(4.75)$ & $(4.15)$ & $(3.86)$ & $(4.18)$ \\
Year F.E. & & & & \\
Observations & Yes & Yes & Yes & Yes \\
R-squared & 1,903 & 2,187 & Yes & Yes \\
\hline
\end{tabular}

Note: The dependant variable is annual loan growth. The models are estimated using ordinary least squares. The crisis variable is a dummy for the years 2008-2009. The dependant variable and all continuous variables are winsorized at the 1st and 99th percentile. Bank level data are sourced from Bankscope, home country ownership data are taken from Claessens and Van Horen (2014a). Bank regulation data are sourced from Barth et al. (2013). Robust standard errors are in parentheses. ${ }^{* * *}$ Significant at $1 \%,{ }^{* *}$ Significant at $5 \%,{ }^{*}$ Significant at $10 \%$. 
Table 10: Sensitivity Testing with Ongena et al Samples. Non-core Banking Activity Regulation

\begin{tabular}{|c|c|c|c|}
\hline & $\begin{array}{c}(1) \\
\text { Western European } \\
\text { Ongena et al Sample } \\
\text { Source }\end{array}$ & $\begin{array}{c}(2) \\
\text { Eastern European } \\
\text { Ongena et al Sample } \\
\text { Host }\end{array}$ & $\begin{array}{c}\text { Ongena et al. Sample } \\
\text { Source and Host }\end{array}$ \\
\hline Non-Core Banking Res & $\begin{array}{l}6.85^{* *} \\
(2.94)\end{array}$ & $\begin{array}{l}-1.37 \\
(1.58)\end{array}$ & $\begin{array}{l}-2.79 \\
(4.93)\end{array}$ \\
\hline Crisis & $\begin{array}{l}-35.60 \\
(22.39)\end{array}$ & $\begin{array}{c}-69.85^{* * *} \\
(18.40)\end{array}$ & $\begin{array}{c}-88.44^{* *} \\
(34.79)\end{array}$ \\
\hline Size & $\begin{array}{l}-2.95 \\
(1.90)\end{array}$ & $\begin{array}{l}-0.53 \\
(1.63)\end{array}$ & $\begin{array}{l}-2.36 \\
(3.13)\end{array}$ \\
\hline Capitalization & $\begin{array}{l}3.15^{*} \\
(1.81)\end{array}$ & $\begin{array}{c}39.62^{* * *} \\
(11.15)\end{array}$ & $\begin{array}{c}42.02^{* * *} \\
(11.08)\end{array}$ \\
\hline Profitability & $\begin{array}{c}-6.10^{* * * *} \\
(1.16)\end{array}$ & $\begin{array}{c}-4.43^{* * *} \\
(0.76)\end{array}$ & $\begin{array}{c}-5.16^{* * *} \\
(1.07)\end{array}$ \\
\hline Deposit Funding & $\begin{array}{c}3.30 \\
(10.07)\end{array}$ & $\begin{array}{c}3.81 \\
(7.29)\end{array}$ & $\begin{array}{c}2.72 \\
(9.57)\end{array}$ \\
\hline Liquidity & $\begin{array}{l}10.55 \\
(13.63)\end{array}$ & $\begin{array}{c}-68.00 * * * \\
(20.17)\end{array}$ & $\begin{array}{c}-81.08^{* * * *} \\
(27.04)\end{array}$ \\
\hline Non-Core Res*Crisis & $\begin{array}{l}-0.72 \\
(3.59)\end{array}$ & $\begin{array}{l}3.03 \\
(2.12)\end{array}$ & $\begin{array}{l}6.81 \\
(5.32)\end{array}$ \\
\hline $\begin{array}{l}\text { Host Country F.E. } \\
\text { Year F.E. } \\
\text { Observations } \\
\text { R-squared }\end{array}$ & $\begin{array}{l}\text { Yes } \\
\text { Yes } \\
743 \\
0.28\end{array}$ & $\begin{array}{l}\text { Yes } \\
\text { Yes } \\
370 \\
0.49\end{array}$ & $\begin{array}{l}\text { Yes } \\
\text { Yes } \\
229 \\
0.50\end{array}$ \\
\hline
\end{tabular}

Note: The dependant variable is annual loan growth. The models are estimated using ordinary least squares. The crisis variable is a dummy for the years 2008-2009. The dependant variable and all continuous variables are winsorized at the 1st and 99th percentile. Bank level data are sourced from Bankscope, home country ownership data are taken from Claessens and Van Horen (2014a). Bank regulation data are sourced from Barth et al. (2013). Robust standard errors are in parentheses. $* * *$ Significant at $1 \%,{ }^{* *}$ Significant at $5 \%, *$ Significant at $10 \%$. 
Table 11: Sensitivity Testing with Ongena et al Samples- Initial Capital Stringency Regulation.

\begin{tabular}{lccc}
\hline & $(1)$ & $(2)$ & $(3)$ \\
& Western European & Eastern European & Ongena et al. Sample \\
& Ongena et al Sample & Ongena et al Sample & \\
& Source & Host & Source and Host \\
\hline Initial Capital Stringency & -2.27 & -5.61 & -7.00 \\
& $(3.38)$ & $(3.62)$ & $(5.65)$ \\
Crisis & $-56.01^{* * *}$ & $-59.40^{* * *}$ & $-62.29^{* * *}$ \\
Size & $(9.51)$ & $(9.05)$ & $(10.18)$ \\
& $-3.54^{*}$ & -1.05 & -2.52 \\
Capitalization & $(1.91)$ & $(1.59)$ & $(3.15)$ \\
& $3.02^{*}$ & $39.47^{* * *}$ & $42.03^{* * *}$ \\
Profitability & $(1.78)$ & $(11.46)$ & $(11.44)$ \\
& $-5.85^{* * *}$ & $-4.39^{* * *}$ & $-5.07^{* * *}$ \\
Deposit Funding & $(1.16)$ & $(0.76)$ & $(1.07)$ \\
& 6.84 & 4.66 & 1.40 \\
Liquidity & $(10.02)$ & $(7.28)$ & $(9.28)$ \\
& 7.81 & $-66.65^{* * *}$ & $-79.57^{* * *}$ \\
Init Cap Strin* Crisis & $(13.74)$ & $(20.27)$ & $(27.51)$ \\
& $8.48^{* *}$ & 5.85 & 7.83 \\
& $(4.03)$ & $(4.07)$ & $(6.60)$ \\
Host Country F.E. & & & \\
Year F.E. & Yes & Yes & Yes \\
Observations & Yes & Yes & Yes \\
R-squared & 743 & 371 & 229 \\
\hline
\end{tabular}

Note: The dependant variable is annual loan growth. The models are estimated using ordinary least squares. The crisis variable is a dummy for the years 2008-2009. The dependant variable and all continuous variables are winsorized at the 1st and 99th percentile. Bank level data are sourced from Bankscope, home country ownership data are taken from Claessens and Van Horen (2014a). Bank regulation data are sourced from Barth et al. (2013). Robust standard errors are in parentheses. *** Significant at $1 \%,{ }^{* *}$ Significant at $5 \%,{ }^{*}$ Significant at $10 \%$ 